\title{
Publisher Correction: Kranthi and Stone reply
}

\section{K. R. Kranthi and Glenn Davis Stone $\mathbb{D}$}

Correction to: Nature Plants https://doi.org/10.1038/s41477-020-00790-0, published online 12 October 2020.

This Matters Arising Reply is related to two separate Matters Arising articles; however, when it was originally published it was missing the reference to the Matters Arising by I. Plewis (Modelling long-term impacts of Bt cotton. Nat. Plants https://doi.org/10.1038/s41477020-00789-7; 2020), which has now been added as ref. 11, and is cited in the sentence beginning "He supports our trends showing that..." A link to this article has now also been added at the head of the Reply. In addition, the title of this Matters Arising Reply has been changed from "Reply to: $B t$ cotton, yields and farmers' benefits" to "Kranthi and Stone reply". All versions of this Matters Arising article have been corrected.

Published online: 17 November 2020

https://doi.org/10.1038/s41477-020-00820-x

(c) The Author(s), under exclusive licence to Springer Nature Limited 2020 